\title{
Hearing rehabilitation through telemedicine to enhance public policies in Brazil
}

\author{
Reabilitação auditiva por meio da Telemedicina para a melhoria das políticas públicas no Brasil
}

\author{
Silvio Pires Penteado ${ }^{1}$, Ricardo Ferreira Bento ${ }^{2}$
}

\begin{abstract}
Since 2004, the Brazilian government has run one of the most allinclusive hearing rehabilitation program based on hearing aids worldwide. In 2007 this investment in hearing aids topped U\$ 68 million, apart from covering the cost of physicians and audiologists. Nearly 140 centers are certified by the government to dispense fitted hearing aids, figures which are still low when one considers the size of the country. Telemedicine can represent a field of knowledge which broadens hearing rehabilitations services in Brazil, for it may help increase the number of hearing rehabilitation centers, enable remote training and provide for an "online second opinion". As far as public administration is concerned, it may enable process standardization and the very control over this hugely complex operation. The present article aimed to consider Telemedicine a powerful ally to improve hearing health care policies in Brazil.
\end{abstract}

Keywords: Telemedicine; Information technology; Public policies; Health economics; Diffusion of innovation; Quality assurance, health care; Rehabilitation of the hearing impaired; Hearing aids

\section{RESUMO}

0 governo brasileiro possui um dos mais abrangentes programas de reabilitação auditiva com base em próteses auditivas acústicas de todo o mundo, que foi iniciado em 2004. Em 2007, foi realizado um investimento social de cerca de $R \$ 146$ milhões somente nessas próteses, além dos investimentos nos atendimentos médico e fonoaudiológico. São cerca de 140 centros credenciados pelo Sistema Único de Saúde - número que pode ser considerado modesto considerando as extensões territoriais do país. A Telemedicina pode emergir como área do conhecimento que amplia os serviços de reabilitação auditiva no Brasil, por permitir, entre outros, que seja aumentado o número de centros credenciados, além de disponibilizar treinamentos à distância e obter a segunda opinião formativa online. No âmbito da administração pública, pode permitir a padronização dos processos e o controle de toda essa complexa operação. Este trabalho teve como objetivo inscrever a Telemedicina como poderoso aliado na melhoria das políticas públicas da saúde auditiva no Brasil.

Descritores: Telemedicina; Tecnologia da informação; Políticas públicas; Economia da saúde; Difusão de inovações; Garantia da qualidade dos cuidados de saúde; Reabilitação de deficientes auditivos; Auxiliares de audição

In a review about Telemedicine, Bashshur et al. ${ }^{(1)}$ stressed the first reports associated with the topic: in 1957, the transmission of radiographic images from the Dieu Hotel in Montreal; and in 1959, the use of closed circuit television to conduct therapy sessions between the Nebraska Psychiatric Institute and the Norfolk State Hospital, $180 \mathrm{~km}$ apart. DeBakey carried out an aortic valve exchange surgery in the Texas Methodist Hospital, being observed by his colleagues at the Geneva University Medical Faculty ${ }^{(2)}$. The spread of medical sciences innovation together with progresses in engineering and information technology promoted the very foundations of Telemedicine.

The United States Department of Health and Human Services ${ }^{(3)}$ defines Telemedicine as "the use of telecommunications technology for medical diagnosis, monitoring and treatment when distance separates the users". As far as its functions are concerned, Tohme et al. ${ }^{(4)}$ reported that Telemedicine "must help patients and medical practitioners, even when located in remote regions, providing the possibility of having primary care or specialized care, with high quality and low costs". Belardinelli et al. ${ }^{(5)}$ noted that the goal of Telemedicine is to increase people's access to a high quality medical care system, at reasonable prices" and "that Telemedicine Technologies may play an important

\footnotetext{
Study carried out at Department of Otorhinolaringology, Faculdade de Medicina, Universidade de São Paulo - USP, Sao Paulo (SP), Brazil.

1 Fundação Otorrinolaringologia - ORL, Sao Paulo (SP), Brazil.

2 Department of Otorhinolaringology, Faculdade de Medicina, Universidade de São Paulo - USP, Sao Paulo (SP), Brazil.

Correspondence: Silvio Pires Penteado - Rua Dr Eneas Carvalho de Aguiar 255, sala 6.167 - Pinheiros - CEP 05403-000 - Sao Paulo (SP), Brazil - Tel.: $113068-9855$ - E-mail: penteadosp@gmail.com

Received: Jul 31, 2010 - Accepted: Feb 11, 2011

${ }^{*}$ Conflict of interest: none.
} 
role in the exchange of medical information between different departments and professionals".

The World Health Organization (WHO) described hearing loss as epidemics ${ }^{(6)}$. Everyone with a hearing loss is a potential user of a hearing aid - an electronic device of selective sound amplification, designed to reduce the effects of hearing deprivation when drug treatment or surgery are not possible or indicated ${ }^{(7)}$. An acoustic hearing aid, known as individual sound amplification device (ISAD), is capable of dealing even with severe sensorineural hearing losses ${ }^{(8)}$.

In October 2004, the Brazilian government established its national hearing rehabilitation program, through Ordinance 587, donating hearing aids to the population by means of its public healthcare system (SUS), with investments of up to US\$68 million in 2007. There are about 140 centers registered at the SUS to serve the population. Despite being free of charge to the patients, there are still complaints, which cause low levels of satisfaction regarding the use of ISADs.

Interested in this topic, researchers from the Department of Otorhinolaryngology of the Medical School of the Universidade de São Paulo (FMUSP) studied such phenomenon and plotted the results in a cause-effect diagram (Ishikawa Diagram), and the main causes were broken down into: patient-related, speech-and-hearing-related, environment-related, process-related and ISAD/fitting-program related, as per depicted on figure 1 .

Among patient-related causes there were difficulties to commute to the clinic". As to the causes associated with speech and hearing, it was found that there are many ISADs of "complex adjustments", that "many ISADs require continuous training", and also that "the professional seemed to be in a hurry when seeing the patient". Asfar as the environment goes, amongst others, it was reported that "the certified clinics were very far away". Among ISAD-related causes, it was reported that the fitting programs are complex and require constant training". As to the process-related causes, the following were listed: "lack of an online technical support", "lack of a training program", "very few SUS-certified centers", besides "non-standard procedures", "non-computerized system" and that "there are no follow-ups concerning ISADs occurrences", and others.

Telemedicine can be seen as a policy for improvement, or even a solution, for the issues stressed in the previous paragraph. Pioneering work from our group provided ISAD remote training and fitting, between the cities

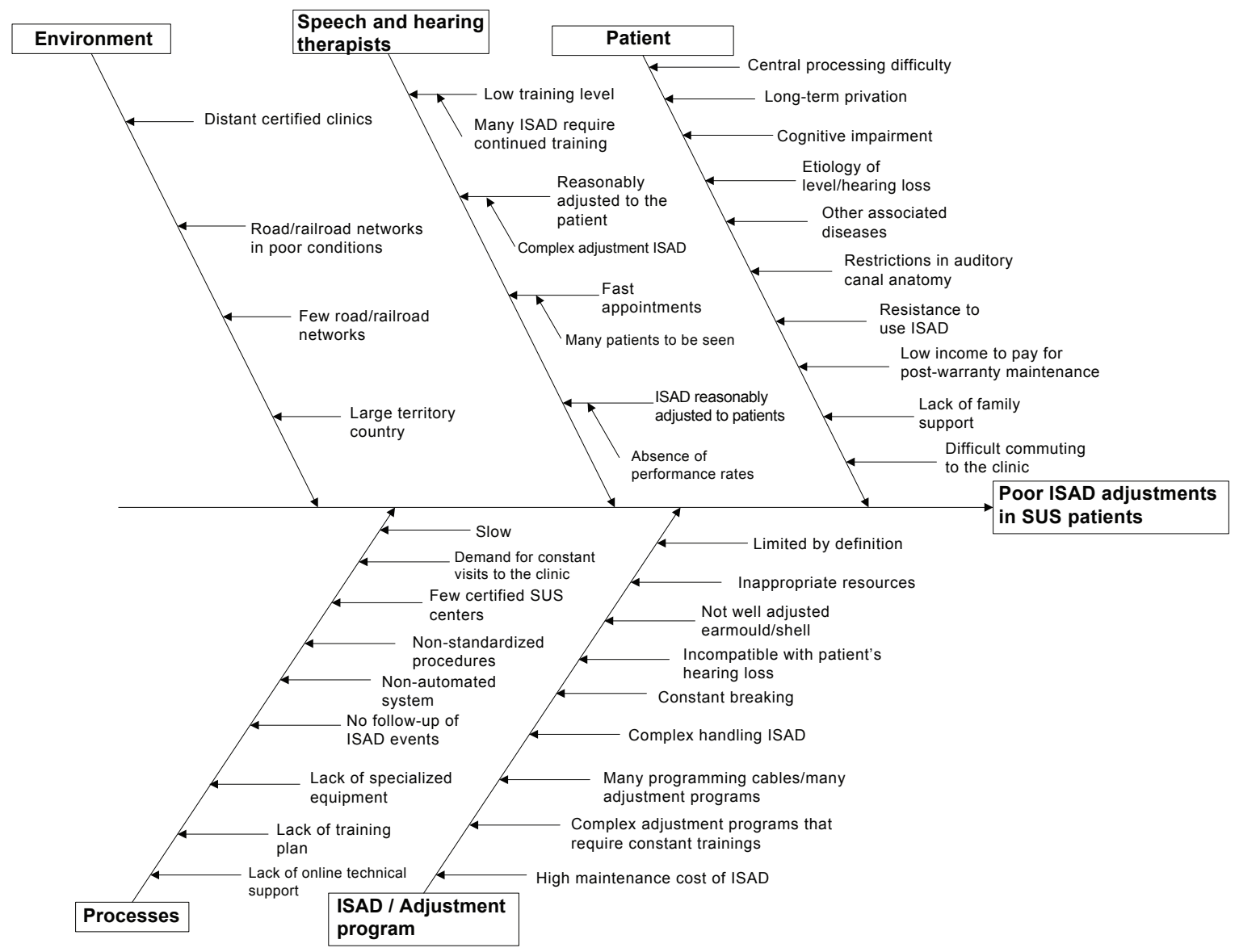

Figure 1. Cause and effect diagram to study the poor adjustments in hearing aids in patients seen by the SUS 
of Sao Paulo (Specialized Unit) and Pouso Alegre and Campinas (Remote Units), which simplified program is depicted on figure 2 .

Ordinance no. 402 from the Brazilian Ministry of Health- February 2010, established the Brazilian Telehealth Program, organized in the form of Telemedicine, with the goals of quantifying and broadening treatment power and to strengthen family health strategies. The Federal Board of Speech and Hearing Therapy published the Resolution no. 366, in April 2009, which defined Telehealth as a legal practice in Speech and Hearing therapy, with the use of information technology (IT). Thus, a way to improve public health policies is seen associated with hearing rehabilitation, based on the principles of general knowledge, the existing technology, as well as the current legislation.

With the implementation of Telemedicine, more centers can be certified, thus increasing patient access to SUS centers closer to their homes, being more comfortable. The complaints stated that continuous training is needed may be solved through teleconference training, or even when a second opinion is needed. Except for these technical issues, it must be stressed the importance of health economics and organization, because when Telemedicine is employed in auditory health rehabilitation, it is possible to manage all the qualified centers together, in such a way as to systematically encompass all its events. Wesendahl ${ }^{(9)}$ used technology resources from the year 2003 to describe fittings and fine tuning of ISADs, and stressed that "Telemedicine helps a highly experienced speech and hearing therapist to be "present" in remote areas without time and geographic restrictions".

As results from pioneering studies, the researchers concluded that by using Internet resources, the speech and hearing therapists from the Remote Unit could receive training from the Specialized Unit in regards of the characteristics of a new ISAD and its fitting program. The Specialized Unit presented and discussed the electroacoustic resources and characteristics of this ISAD at the Remote Unit. The patients interacted with the speech and hearing therapists from both units and approved the remote fitting, stressing the good subjective quality of the ISAD they tried.

\section{ACKNOWLEDGEMENTS}

Research support source: Fundação Otorrinolaringologia - ORL, Sao Paulo (SP), Brazil.

\section{REFERENCES}

1. Bashshur RL, Reardon TG, Shannon GW. Telemedicine: a new health care delivery system. Annu Rev Public Health. 2000;21:613-37.

2. DeBakey ME. Telemedicine has now come of age. Telemed J. 1995;1 (1):3-4.

3. U.S. Department of Health and Human Services. Telemedicine for the Medicare Population: Evidence Report/Technology Assessment Number 24. July 2001.

4. Tohme WG, Hayes WS, Mun SK, Komo D, Meissner MC. Designing a telemedicine platform for three different medical applications. Proceedings of 4th International Conference on Image Management and Communication (IMAC's 95), 1995:86.

5. Belardinelli A, Franchi D, Bedini R, Ripoli A, Palagi G. Ward informative system: hospital application of telemedicine. Computers in Cardiology.1999;26: 413-6.

6. World Health Organization. Situation review and update on deafness, hearing loss and intervention programmes: proposed plans of actions for prevention and alleviation of hearing impairment in countries of the South-East Asia Region. SEA-Deafness-10;Dec. 2007.

7. World Health Organization. Deafness and hearing impairment survey: Report of the consultative meeting of principal investigators. SEA-Deaf-4; 2001.

8. Bento RF, Miniti A, Marone SAM. Tratado de otologia. São Paulo: EDUSP; 1998.

9. Wesendahl T. Hearing aid fitting: application of Telemedicine in Audiology. Int Tinnitus J. 2003;9(1):56-8.

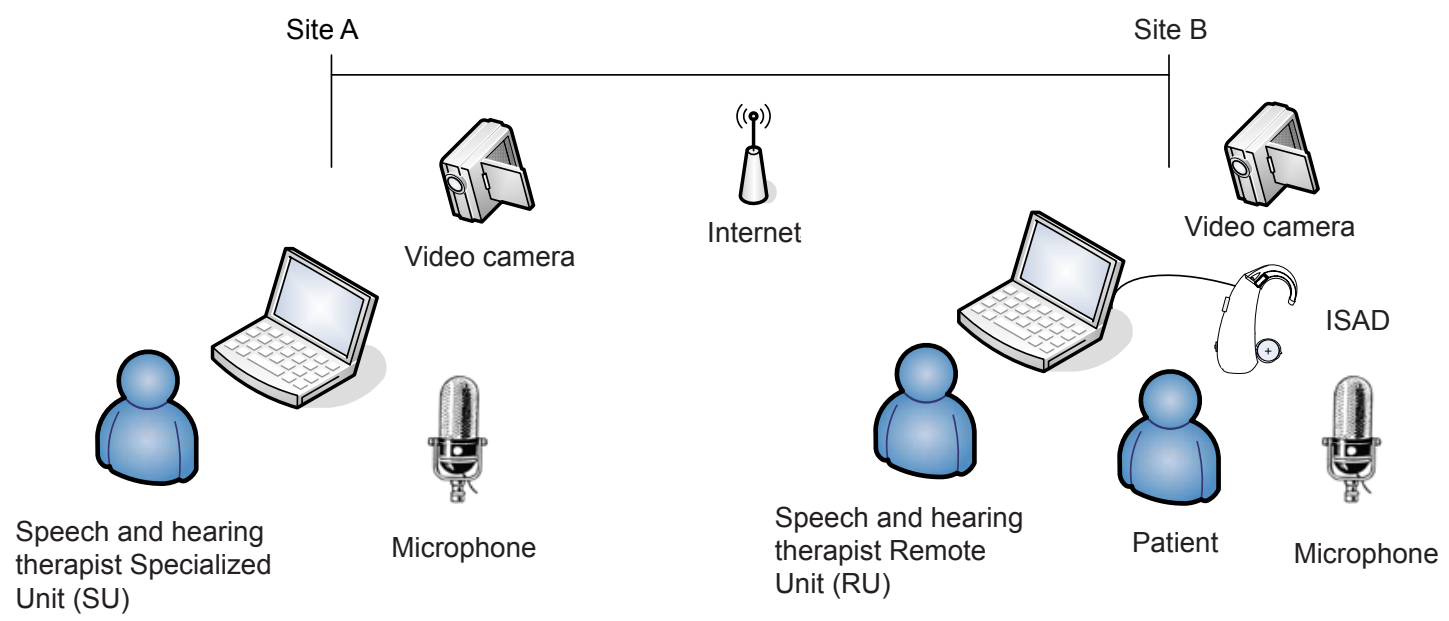

Figure 2. Simplified diagram of a Telemedicine session on hearing rehabilitation 